DOI: https://doi.org/10.31874/2309-1606-2021-27-1-4

удК 130.2:371

\title{
Володимир Волковський
}

\section{Незалежність у протистоянні 3 «русским миром»: філософсько-педагогічний вимір}

У статті автор аналізує окремі політичнофілософські виміри і перспективи, що постають актуальними з нагоди 30-літнього ювілею Незалежності України. Автор, позиціонуючи себе насамперед в межах політично-філософсько-

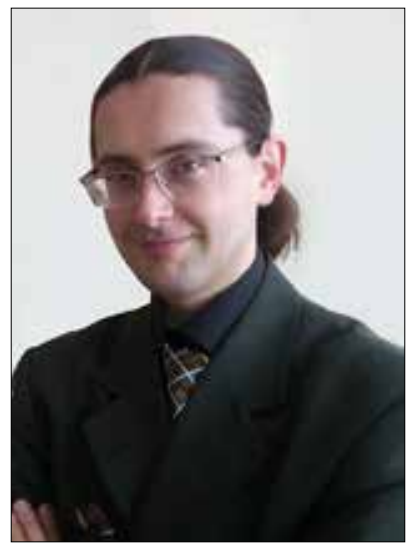
го та філософсько-історичного дискурсу, виокремлює декілька фундаментальних моментів, значущих для ідентичності і позиціювання українського суспільства стосовно "вічних питань українського суспільства», таких як дискусї довкола національної ідеї, національної ідентичності, історичної і просторової перспективи. Виклад автора поділяється на чотири пункти: столітня перспектива украӥнської боротьби за незалежність, політичнофілософське визначення сучасної української ситуації у контексті процесів націєтворення і протистояння з Росією, теоретичний вимір понять «національна ідея» $i$ «громадянська релігія», практичні висновки щодо українського різновиду цих понять. Автор спирається на методологію сучасних Nationalism Studies, Postcolonial Studies, досвід українознавчих досліджень, особливо епохи становлення украӥнської модерності (XIX - ХХ ст.). Він постулює, що тридиятиліття української незалежності невідривно пов'язане із століттям визвольних змагань української нації, що ситуація в Україні, зокрема у контексті визначення національної ідентичності та протистояння з Росією, можна коректно описати як протистояння індепендентистів повсталої нації і колоніальної імперії, що змагається за відновлення своєї влади над колишньою колонією-провінцією, спирається на численних своїх лоялістів та застосовує різні методи агресії (як «холодна» культурна війна, так і «гаряче» військове протистояння) для упокорення регіону. Автор пропонує свій погляд на поняття «української національної ідеї», спираючись на базові літературні джерела історії українського націєтворення. На підставі проведених досліджень автор пропонує певні практичні висновки, що важливі для викладання предметів історії, правознавства, громадянської освіти та для виховання відповідального громадянина в Україні.

Ключові слова: незалежність України, націєтворення, Nationalism Studies, Postcolonial Studies, політична філософія, національна ідея, національна ідентичність, громадянська релігія, громадянська освіта.

(C) В. Волковський, 2021 


\section{Замість вступу: столітня війна за Незалежність}

Проблематика громадянської освіти, виховання відповідального громадянина Української держави - особливо актуалізується у контексті святкування ювілею Незалежності України. Таке виховання передбачає міждисциплінарні компетентності, що включають в себе, зокрема, компетентності у царині історії, політичної філософії та теорії держави і права, української мови, літератури і культури. Важливе місце у цьому посідає те, наскільки учень, майбутній громадянин, розуміє та усвідомлює історичну і культурну реальність України, відповідаючи на питання «що є, звідки і коли починається, що охоплює Україна?». Питання нетривіальні, а відповідь на них має криваві наслідки - межі, до яких сягнула російська пропаганда, яка спричинилася до війни, прямо корелюють із межею поширення певних уявлень про українську історію, культуру, ідентичність. Підтримка ідеологем доктрини «Русского мира» і подій «русской весны» прямо корелювало з запереченням об'єктивного існування України, іï історичної тяглості, зі ствердженням іiї штучності і накинутості, сакралізацією Росії, СРСР, подій ІІ світової війни: висловлювання «Україну видумали», «мы исконно русские», «ми проти фашистівбандерівців», «діди воювали» тощо. Саме тому ми повинні актуалізувати роздуми про українську ідентичність, те, чим $є$ Незалежність України - і зробити з них практичні висновки, корисні для предметів історії, правознавства, громадянської освіти. Це потребує глибокого занурення у те, чим $\epsilon$ і що значить Україна, її Незалежність, поняття національної ідеї, як можна мислити її історію та як можна ï концептуалізувати у політично-філософських термінах.

Коли ми говоримо про урочисте святкування 30-літнього ювілею Незалежності України, те, про що найперше хочеться нагадати - вже 4 роки маємо 100-ліття славних Перших Визвольних змагань. На 2021 рік випадає дві ювілейні дати - 100 років від завершення цих змагань, трагічного і кривавого, остаточного розгрому УНР і Голодомору, але і 30-ліття відновлення Незалежної Української Держави, що постала у 1991 p.

Це - не просто календарний збіг. Між цими подіями - сутнісний історичний і політичний зв'язок. Настільки важливий, що збагнути, розуміти це - критично необхідно, актуально, як для викладання історіï, політології, фрілософії у школі, так і і в контексті виховання відповідального громадянина і моральної людини. Це - питання про нашу екзистенційну і громадянську ідентичність, пам'ять, відновлення спадкоємності традиції. Зрештою, це - питання про наше майбутнє як спільноти і як держави.

Це - горизонт смислів, ідей та цінностей, які необхідні для успішного формування українського суспільства, для виховання того майбутнього 
покоління, яке житиме на цій території. Саме ідеї, смисли і цінності визначають мотивацію поведінки окремих індивідів і цілих спільнот, а тим самим визначають політику і суспільне життя цілих поколінь. Хибна настанова свідомості (mindset) веде до схиблення способу життя цілих суспільств. Розуміння певної історичної картини - системно значуще для такої справи.

Саме тому нам конче необхідно розташовувати ювілей Незалежності в контексті роковин Визвольних змагань і Української революції 1917 1921 рр. Це треба для того, щоб не виникала хибна ідея «Україні тридцять років». Ця ідея часто виголошується різними адептами доктрини «Русского мира», з метою знецінити реальність України як такої. Поряд із ідеями «видуманості і штучності України», яку нібито створив чи то Габсбурги, чи то поляки, чи то більшовики і особисто Ленін та Сталін, які і «зробили українські кордони», нібито відсутності української нації чи національної ідеї, нібито одвічної розділеності України на Схід і Захід - така ідея є сильним індикатором, що їі спікер є свідомо чи несвідомо адептом «русского мира».

Історія української модерної нації (якщо ї̈ аналізувати через методологію сучасних Nationalism Studies) починається з ХІХ ст., вперше експліцитно маніфестується у текстах Кирило-Мефодіївського братства (1846 р.) та маніфесті Головної Руської Ради (1848р.) [Бутич et al. 1990], і саме з 1917 - 1918 рр. ми ведемо генеалогію Української Незалежності. Це розташовує Українську Державу поряд із малими балтійськими державами чи Польщею, що також здобули незалежність у цей час і втратили її у 1939 - 1940 рр., були понад 40 років окупованою частиною СРСР, але тим не менше не забували, що за ними стояла їхня Незалежність, яку вони відродили. У цьому ж ряді - Фінляндія, якій пощастило трохи більше, і вона змогла захистити свою незалежність у 1939 - 1945 рр. Такий контекст відкриває великий простір для компаративних досліджень історії суспільств і держав Центральної та Східної Європи - які всі постали приблизно в один час, були наслідком приблизно тих ж самих модерних націєтворчих процесів, але доля яких мала буквально протилежні траєкторії. Які фактори, рішення, сили впливали на формування цих траєкторій - це питання актуальне і для нашого часу, для сучасних політичних, соціологічних та економічних досліджень. Як формується і занепадає нація-держава? У чому секрет тривання і успіху? Why and how a nation fails, перефразовуючи відомий бестселер [Робінсон 2016]?

22 серпня, у переддень першого святкування дня Незалежності, президент Української Народної республіки в екзилі (у вигнанні) Микола Плав'юк урочисто, у присутності президента, голови Верховної Ради і прем'єр-міністра України склав повноваження Державного Центру (ДЦ) 
УНР і проголосив молоду державу правонаступницею УНР [1992 ... 2012], а саме тієї, яку очолювала Директорія УНР. Цим символічним актом було засвідчено, що Незалежна Українська Держава відродилась у 1991 р., і ії політична спадкоємність чітко зафіксована у відповідних офіційних актах - це, з одного боку, УРСР, з іншого боку, УНР. Враховуючи, що саме постання УРСР (УСРР) у 1917 р. апелювало до постання УНР під проводом УЦР (Центральної Ради), то можна в межах політично-філософської коректності стверджувати, що це було відродження Незалежної України, що тривала (у екзилі чи під окупацією) з 1917 р.

Це дуже важливо з точки зору легітимності і спадкоємності. Відповідно, Україна несе моральну і політичну відповідальність (максимум!) за ці політичні утворення (а в ідеалі, лише за УНР, оскільки УСРР-УРСР не була незалежним політичним формуванням), натомість одіозні полеміки довкола інтерпретації діячів II світової війни (зокрема, різних видів ОУН, різних видів УПА, радянської влади чи місцевої поліції тощо) не можуть накладати на Україну жодних зобов'язань - ніхто з них не діяв як уповноважений представник і репрезентант цілого Українського народу та його Держави.

\section{На позвах зі смертю або від Крут до Іловайська: політично-філософський погляд}

Отже, історія Незалежності почалась 100 (уже 104) роки тому, і триває далі. Епохальна перемога 1991 року і тривалий мирний період по тому справив на українське суспільство фатальне враження - оману того, що Україна вже сталася, як fait accompli, і зараз можна просто зосередитися на внутрішніх справах, економіці, відкритті шкіл, побудові мостів і мріях про захмарне майбутнє. Історія вогню і льоду, кривавої битви за свободу - це лише історія, яка минула, яку можна героїзувати, але краще критикувати, і взагалі залишити минуле минулому. Істориків та українських націоналістів часто висміювали за те, що вони реанімують привидів і війни минулого, заважаючи будувати мирне теперішнє у спільному світі. Навіть тривожні маячки Кримської кризи 1994 р., конфлікту довкола Тузли 2003 р., російської інформаційної агресії з 2004 p., грузинська кампанія 2008 р., путінські демарші 2007 та пізніших років - не збудили пильність українського публічного простору. Крик про російську загрозу зоставався воланням у пустелі, ознакою націоналістів та істориків. 2014 рік справдив їхнє волання, але і надалі до них не дуже прислуховуються.

Війна, що почалась з російського збройного вторгнення 2014 р., досі не здобула однозначної оцінки серед українських інтелектуалів і політичного суспільства. Хоча переважна більшість погоджується, що це 
віроломна російська агресія проти України у стилі гібридної війни, проте понад 30\% населення підтримує сили, які дозволяють собі називати стан в Україні «громадянською війною» і закликати українців до примирення (так, ніби жертва повинна «примиритися» з агресором, в той час, коли агресія ще у повному розпалі).

Чому ж діалог з тими, хто підтримує такі позиції, що є також індикаторами доктрини «Русского мира», ніяк не вдається? Чому попри війну в Україні лишається велика частина людей, що дозволяє собі «любити Росію», «відділяти Пушкіна від Путіна», а «Путіна від Росії», вірити в «ультранаціоналістів, фашистів і бандерівців» в Україні? Як розуміти сучасну війну? Де її можна розташувати у контексті Української столітньої війни?

Для того, щоб відповісти на ці питання, слід здати собі справу із головним питанням: який є головний сюжет ${ }^{1}$ і головні дієвці цієї війни? Спробуємо це зробити, спираючись на досвід сучасних Nationalism Studies, Postcolonial Studies, досліджень посттоталітарних і постгеноцидних суспільств, зокрема у контексті колективної травми і ПТСР.

Ця війна має два виміри - власне український і глобальний всесвітньо-історичний.

Всесвітньо-історичний вимір постає в контексті Першої світової (на Заході часто називається «Великою») війни, основний сюжет якої - протистояння регіональних держав-імперій за перерозподіл сфер впливу і за владу над світом. Друга і вторинна лінія історії - триваюча (ongoing) націєтворча модернізація європейських суспільств, в процесі якої формувалися нові нації-спільноти, які прагнули здобути незалежності як нації-держави, а старі імперії «націоналізувались», перетворюючись 3 легітимістичних наднаціональних формацій у модерні нації-держави з відповідним ядром і периферією. На теренах Центрально-Східної Європи ці дві лінії наклалися суперпозиційно: нові нації-спільноти відчайдушно змагались проти асиміляції в межах старих націй-держав, а старі нації-держави переживали складні процеси узгодження своєї політичної практики із новою політичною теорією та ідеологією. Все це накладалось на глобальний процес модернізації та гуманізації політичного дискурсу - відомий як становлення модерних понять прав і свобод людини і громадянина, що був у свій час концептуалізований в українському контексті Михайлом Драгомановим як «поступ у розумі, свободі та людськості», а сучасний французький політичний філософ П’єр Манан сформулював це як становлення двох вищих авторитетів модерного суспільства - Науки і Свободи [Манан 2009: 4]. Проте цей

\footnotetext{
${ }^{1}$ В оригінальному значенні слова sujet - одночасно «суб'єкт», «предмет», «матерія» і «сюжет».
} 
глобальний процес у Центрально-Східній Європі був відсунутий на задній план. Як наслідок, наша частина Європи перетворилася на bloody lands, за влучним висловом Т. Снайдера, а наша історія - на «затемнення» (Tenebrae) за Н. Девісом.

Якщо взяти за визначення, що війна триває доти, доки не розв'язана ії головна суперечність, тобто її сюжет не досягне свого розв'язку (як у теорії драми, або як у Пунічних війнах), то Велика війна, що почалась 1914 р. і полягала у завершенні трансформації старорежимних імперій у модерні нації, не завершилась досі. Якщо Англія, Франція, Німеччина, Австрія тощо пройшли цю трансформацію, то остання імперія Європи Росія - навіть її не починала. Внаслідок революції і громадянської війни 1917 - 1922 рр. Російська імперія трансформувалась у російську Республіку Рад, а до 1934 р. процес відновлення імперського формату урядування було завершено. Для демонтажу імперського формату потрібно було дві головні речі: змінити авторитарне управління підданими незначною елітою на реальний демократичний суверенітет громадянського суспільства і в межах нового демократичного громадянського суспільства дати собі раду із розмаїтими поліетнічними «окраїнами» імперії. Що перше, що друге здобуло однаково формальне і фейкове здійснення: «народна демократія» за повним диктатом ВКП(б) - КПРС, «гуманна конституція» за умов Великого Терору, «національні республіки», які були перетворені на регіональні підрозділи «демократично-централізованої» партії.

Подальші великі війни у Європі - це продовження того ж сюжету «імперій, що прагнуть реваншу»: спочатку Німеччина, потім СРСР, який претендував на свій перерозподіл сфер впливу, зрештою, сучасна РФ прямо заявляє про політику «регіональних центрів і сфер впливу» у дусі колоніалізму XIX століття.

Розгляд російської і радянської офіційної ідеології - окрема подальша розмова, поки що досить засвідчити, що в межах будь-якого російського (що «білого», що «червоного») наративів Україна мислилась як не просто невід'ємна частина, але як стратегічна і катастрофічно необхідна. Саме тому конче необхідно було довести, що українці $є$ якщо не один з росіянами народ («русские» чи «малоруссы», у російсько-імперській версії), то принаймні «майже один» (три братні східнослов'янські возз'єднані народи - радянська версія), влучно назване «Триединая Русь - земное подобие Троищы» (російський православний співак ієром. Роман (Александр Матюшин)). Сучасна Росія певний час вагалась у формулюванні свого ставлення до України: від презирливо-знецінюючого «Прощевайте, хохлы! ... Вашего неба, хлеба нам - подавись мы жмыхом и потолком - не треба... С Богом, орлы, казаки, гетманы, вертухаи!» М. Бродського, простого (і рідкісного) прийняття існування українців та 
України як окремої політичної сутності, до проектів повернення її в орбіту впливу московського центру і повного заперечення існування України як взагалі якоїсь реальної сутності, народу і держави.

Це і є головний сюжет. 3 одного боку, є повстала модерна націяспільнота, яка змагає до незалежності нації-держави, яка спирається на відповідне етно-мовно-культурне ядро (українське), але вже давно трансформувалася у політичну націю, яка охоплює (або претендує охопити) всіх мешканців певної території, а не лише певну етнічну спільноту. 3 іншого боку - колоніальна імперія, яка розглядає цю територію як свою стратегічну провінцію, так чи інакше заперечує саме право на існування цього народу і його будь-якої реальної держави. Обмежене «визнання» як етнографічної «родзинки» (з шароварами і варениками) чи як формальної політичної одиниці (автономії чи навіть формальної незалежності) - миттєво нівелюється реальними домаганнями, які унеможливлюють будь-яку реальну незалежність, провокують активну асиміляцію. Така політика не є унікальною - ще Драгоманов показував аналогії у Франції щодо Провансу, Іспанії щодо Каталонії, Британії щодо кельтських окраїн тощо. В усіх випадках ми бачимо ідеологічне поєднання маніпуляції та знецінення у будь-якій його формі.

Будь-які дослідження дискримінації різних суспільних груп (будь-то жінки, темношкірі, ЛҐБТ, тощо) засвідчать, що знецінення і набір маніпуляцій завжди присутній (починаючи з газлайтингу, тобто коли агресор заперечує відчуття жертви, нав'язуючи їй сприйняття, ніби її відчуття хибні і нічого такого немає).

Отже, випливають три висновки, значимі, зокрема, для коректного викладання історії і розуміння смислу сучасних історичних та політичних подій.

Події війни не коректно описувати в категоріях громадянської війни чи внутрішнього протистояння. Просте порівняння із «ідеальними типами» таких категорій (громадянська війна в США, в Росії чи Іспанії) передбачає, що це - розкол однієї громадянської спільноти на дві частини, кожна з яких має протилежні візії щодо майбутнього того ж самого політичного тіла. Тобто, обидві частини мають за предмет непримиренної суперечки одне політичне тіло, яке служить фреймом дискурсу. В Україні обидві спільноти мають в умі різні політичні тіла і різні політичні центри ${ }^{1}$.

\footnotetext{
${ }^{1}$ Одна - $з$ політичним центром у Києві, що мислить себе як Україну, в межах українського горизонту, віддана побудові України. Друга - з ментальним центром у Москві, у «широкой стране... от Москвы до самых до окраин». Друга група ставиться до України по-різному, проте ії спільною рисою є заперечення рівності України і «центру»Росії, різні форми та способи применшення та знецінення.
} 
Відповідно, це не можна описувати у категоріях регіонального протистояння і боротьби окремих регіонів за незалежність. Порівняння із «ідеальними типами» боротьби за незалежність будь-якої етнічної провінції Європи (від Каталонії до Шотландії) передбачає наявність окремої етнічної групи і змагання до власної незалежної держави. Тобто ментальному фрейму держави (політичній нації-державі як «уявленій спільноті» 3 їі «ідеальним часом історії» та «ідеальною територією») протистоїть інший аналогічний образ, центр якого також у собі самому. В Україні опоненти української нації - належать до уявленої спільноти з центром у Москві і Росії. Це скоріше схоже на Судети і нацистське збирання фольскдойчів, аніж на типовий індепендентизм.

Натомість, це дуже схоже на Американську революцію, де відбувається протистояння індепендентистів модерної молодої нації із лоялістами старорежимної імперії', яка розпочинає свою інтервенцію, спираючись на лоялістичну частину суспільства. Поєднання ностальгії та ресентименту - дуже важлива складова у мотивації лоялістичної частини суспільства, яка використовується під час гібридної агресії.

Риторика РФ у протистоянні із Заходом показує, що події в Україні не $\epsilon$ подіями локального значення, але вбудовані у широку панораму реваншистської політики нової Російської імперії. У певній мірі можна сказати, що маємо справу з незавершенням того самого сюжету Великої війни, черговий раунд якої ми бачимо зараз.

\section{Громадянська релігія, сакральний час і простір: на прикладі США}

Ювілей такого роду спонукає «вічні прокляті українські питання» про українську національну ідею, пошуки об'єднавчого наративу, смисл і призначення буття України тощо. Мимоволі напрошується паралель із активними дискусіями у США з нагоди 200-річчя Американської незалежності та фундаментальних цінностей американського суспільства, які соціолог Роберт Белла назвав громадянською релігією

\footnotetext{
${ }^{1}$ Я свідомо не називаю імперію російською чи радянською. Це - РФ, яку можна назвати російсько-радянською імперією, але насправді вона являє собою специфічний світоглядний політичний феномен. Сучасна російська ідентичність - явище доволі складне, розмаїте і неоднорідне. Громадянська релігія сучасної РФ включає в себе різнобічні елементи. Деякі елементи запозичені із СРСР, деякі включені із дорадянської історії Росії, деякі формуються просто зараз. Вона включає в себе доктрину «русского мира», що спирається на ідеологему «тисячолітньої нерозривної тяглості Російської Держави», яка претендує на привласнення усього, що історично носило імення «руського», та на космогонічно-політогонічний міф «Великої Вітчизняної війни». Проте, справи набагато складніші, але аналіз російської політичної свідомості виходить за межі цієї статті.
} 
США або релігійним виміром американського політичного життя [Bellah 1967].

Визначення публічних загальновизнаних цінностей як громадянської релігії вказує на дуже важливий бік цих цінностей, уявлень та ритуалів - їхній релігійний, тобто сакральний вимір. Р. Белла продовжує функціоналістичний підхід свого вчителя Т. Парсонса, коли наголошує, що релігія є важливою системою функціонування суспільства, що забезпечує його трансцендентну легітимацію, і Е. Дюркгайма, який визначав релігію як систему вірувань і практик, що об'єднують групу людей у певну стійку моральну спільноту. У термінах П. Бергера, релігія формує сакральний космос певного суспільного світогляду, який містить у собі і визначає сакральний простір і час, хронотоп. Перефразовуючи це у термінах Бенедикта Андерсона [Миллер 2013: 18 - 19, 288], нація як уявлена спільнота визначає свою «ідеальну територію», яку вона вважає за «свої природні межі», та «ідеальну історію» або історичний канон, який описує (одвічну) генеалогію нації.

Феноменологічний підхід до визначення релігії фокусується на змісті акту свідомості, який кваліфікується як релігійний ${ }^{1}$ - на поняття «сакрального / священного». Сакральне визначає дві важливі якості:

1) воно позначає певну трансцендентну щодо суспільного та індивідуального буття реальність, яка є більш реальною, ніж «поцейбічна» реальність. Саме тому воно легітимує поцейбічне буття надсвітовою метою - воно відповідає на питання смислу, причому смислу не стільки життя (яке і так дане як даність an sich), скільки смерті, не стільки «заради чого варто жити (разом)?», скільки «заради чого можна і варто померти?». Це - радше питання про смисл смерті в ім'я певної спільноти і тотальності;

2) сакральне, яке має два виміри - mysterium tremendum i mysterium fascinans - від початку передбачає активне емоційне, афективне, ірраціональне ставлення. На відміну до абстрактної офіційної ідеології, яка може бути предметом абстрактного раціонального мислення, сакральне як феномен і як переживання є глибоко афективним. Це радше про любов, аніж про розум.

Саме тому Митр. Любомир Гузар мав глибоку рацію, коли сказав: «Немає розколу між Сходом і Заходом України, а є між тими, хто любить Україну і хто її не любить». В основі політичного вибору стоїть не аргумент ex ratione, а ordo amoris. Афективна синтетична та синестетична

\footnotetext{
${ }^{1}$ Враховуючи, що сучасне поняття «релігія» $є$ доволі проблематичним - воно історично сформоване у ранньомодерну епоху і має проблеми із тим, що чітко і однозначно вхопити своє позначуване, об'єкт, який воно претендує позначати.
} 
відданість певній спільноті, ідеї, нації тощо - визначає майже ірраціональну прив'язаність індивіда до української чи радянсько-російської національної спільноти та ідентичності. Наявність афективних та естетичних компонент серйозно ускладнює діалог і примирення - яке завжди має за основний інструмент раціоналізацію власного ставлення і відкритість до іншого.

У соціології релігії є розрізнення між поняттями «культ спільноти» та «релігійна спільнота» [Казанова 2017: 25] ${ }^{1}$. У культі спільноти - певної конкретної племінної, етнічної чи політичної - сакралізується сама спільнота як $\epsilon$, an sich - у його ритуалах «святкується» і «святиться» сама спільнотність, буття-у-спільноті (Mitsein), спільнотворення і успільнотнення людей. Релігійна спільнота об’єднує людей довкола певного сакрального, певних релігійних уявлень і практик.

У добу секуляризації «старі типові» релігії відходять на задній план Ж.-Ж. Руссо, який і впровадив поняття «громадянська релігія», у «Суспільній угоді» проголошує, що старі релігії ворожі до Республіки, бо вони розривають душу громадянина, створюють подвійну лояльність, а вірні Церкви по суті становлять розгалужену агентуру ворога на теренах Республіки ${ }^{2}$. Тому треба створити «громадянську релігію», яка плекатиме чесноти Громадянина, чия «релігійна спільнота» буде тотожна «культові спільноти», а їі межі збігатимуться з межами політичної спільноти, яка сама і буде предметом пошанування. Догми цієї релігії ${ }^{3}$ мають бути прості, нечисленні, висловлені чітко без інтерпретацій і коментарів.

\footnotetext{
${ }^{1}$ Тут я спираюсь на класичні джерела з соціології релігії: Е. Дюркгайм, Р. Белла, Х. Казанова, а також В. Гараджа (у пострадянському просторі), але також К. Ясперс, Р. Отто, М. Еліаде та ін.

${ }^{2}$ Це дуже нагадує риторику дискусій щодо ролі РПЦ і їі підрозділу УПЦ в Україні. Попри всі відмінності ситуації, аргументи обох сторін майже повністю нагадують стару дискусію довкола ідей Руссо - «стара» релігійна спільнота пропонує таку відданість, що ворожа «новій» Республіці. Ці дебати аналогічні до дебатів часів Французької Революції чи політики нативізму XIX - XX ст. у США щодо ролі Католицької Церкви - коли вважалось, що католики, оскільки їхній «центр управління» знаходиться за межами держави, $\epsilon$ потенційною «п'ятою колонною», ворогами держави (республіки, нації) і свободи, що у випадку конфлікту Вашингтону чи Парижу з Ватиканом, «ми» отримаємо внутрішній фронт зрадників. Звісно, історія відмінна - Ватикан, яким би він не був, завжди був суверенним дієвцем, тоді як РПЦ $є$ підлеглою і вторинною щодо влади РФ і ФСБ.

зу Руссо - це чотири догми: «Існування могутнього, мислячого, добродійного божества, яке усе провидить іусім наділяє, прийдешнє життя, блаженство праведних, покарання тих, хто чинить зле, святість суспільної угоди (contrat social) і законів - такими $\epsilon$ позитивні догмати. Негативні я б обмежив одним єдиним - це нетерпимість, саме нетерпимістю позначені ті культи, які ми виключили» (У праці «Про суспільну угоду», 1762, книга 4, гл. 8 [Руссо 2001])
} 
Така «релігія» повинна обгрунтовувати смисл і призначення спільного буття разом цілого суспільства, давати трансцендентний горизонт оцінки подій, пояснити, заради чого ми всі повинні разом жити, жити задля цілого i, головне, померти за нього. Проте якби така релігія мала за свій предмет лише саму себе, вона була б ірраціонально і афективно слабкою, непереконливою. «Культ спільноти» $є$ вторинний у межах логіки сакрального - він потребує бодай ерзацу справжнього сакрального, тобто відсилок до чогось трансцендентного і священного, які здебільшого запозичуються із більш «типових» релігій ${ }^{1}$.

Саме плекання такої громадянської релігії $\epsilon$ насамперед задачею школи - про це пише Р. Белла. Саме школа - як через викладання історії і літератури з відповідними акцентами, так і через громадянське виховання, через святкування, шанування символів і дат, героїв і пам'ятників, плекання відповідної пам'яті - формує цей сакральний космос. Тому не варто до цього ставитись псевдо-ліберально - хто скаже, що США не демократична країна?! - бо кожний момент пам'яті (від вшанування героїв і пам'ятників, до державних свят і шанування символів) завжди чітко відносить нас до конкретного сакрального космосу, плекає у вихованців конкретні відданості. «Абстрактної» пам'яті «людей і наших дідів» немає. Це або сакральний космос України, або чийсь інший.

\section{Українська громадянська релігія або Чи марні пошуки національної ідеї?}

Американські дискусії довкола громадянської релігії - аналогічні до «проклятих» українських дискусій про «українську (об'єднавчу) національну ідею». Впродовж 30 років безліч зібрань високочолих і поважних осіб обговорювали цю тему, безліч списів було зламано в ЗМІ і на конференціях, купу програм партій переписано. I досі обговорення на цю тему - так ніби вперше і ніхто нічого досі про це не писав і не говорив.

Але важко знайти Грааль і філософський камінь, а тим паче у темній кімнаті чорну кішку, якої там немає і яку взагалі знайшли давно. Я свідомо загострив і зараз спробую заспокоїти читача, на основі того, що писалось раніше.

\footnotetext{
${ }^{1}$ Наприклад, у випадку США культ Американської республіки (що виражається у вшануванні державних символів, ветеранів, пам'ятників революції, пошануванні минулих і живих політичних лідерів, тощо ) спирається на переконання щодо особливої американської місії та проведення прямих аналогій між історією біблійного Ізраїлю та сучасної Америки (Вихід з Єгипту через море, Земля Обітована, Американський Ізраїль, заповідь «просвітити весь світ», т.зв. Manifest Destiny, нести світло Боже (і демократії) усім народам, бути зразком для всіх народів). Натомість наші часи позначені глибокою кризою американської громадянської релігії.
} 
Мова йде про більш чи менш успішне формування української громадянської релігії. Це означає формування сакрального космосу української нації (=уявленої політичної спільноти), що включає в себе наступні важливі елементи:

1) Сакральний простір (ідеальна територія, яка мислиться як «наша», байдуже, де і яка вона і хто нею управляє);

2) Сакральний час (історичний канон героїв нації та історична ідеалізована генеалогія української нації, кажучи словами класика, «хто ми, чиїх батьків, ким, за що закуті?»);

3) Сакральний культ конкретної політичної спільноти (відданість самій Україні, шанування ії сакральних символів тощо);

4) Трансцендентний сакрально-моральний горизонт, який легітимує смисл і призначення України у світлі всесвітньо-історичної місії, глобального вселюдського спільного майбутнього та взагалі sub specie aeternitatis.

I щоб не винаходити «секрет Полішинеля» і бідну чорну кицьку, звернемось до загальновизнаних висновків Nationalism Studies. Ці висновки (звісно, сильно спрощуючи - бо обсяг не дозволяє ширших викладок) можна скоротити до таких пунктів:

1) Концепт нації містить об'єктивну і суб'єктивну складову. 3 одного боку, будь-яка модерна нація-держава є уявлена політична спільнота (imagined community) і суто модерним витвором, наслідком модернізації суспільства. Він завжди відбувається у конкуренції різних націєтворчих проектів. 3 іншого боку, цей витвір і проект завжди має певні відсилки до об'єктивної реальності, яка надає йому джерела власної аргументації. Це - наявність реального етносу-народу, його межі розселення, кордони вже усталеної державності, історичні кордони обраної держави, сучасні офіційне загальносвітове визнання кордонів;

2) Існують 2 умовні ідеальні типи нації: етнічна і політична. Але це штучні типи, які на практиці не існують. Будь-яка «етнічна нація», здобувши певне політичне «тіло» (автономію чи незалежність), мусить дати собі раду з непозбутньою різноманітністю населення підконтрольної території, якось його асимілювати чи інтегрувати, i внаслідок цього завжди стає політичною нацією. Будь-яка політична нація має жорстке етно-мовно-культурне ядро, при цьому тяжіє до одномовності ${ }^{1}$.

${ }^{1}$ Докладніше про різні способи формування націй - напр.., «від держави до нації» $\mathrm{i}$ «від нації до держави», я пишу у гл. «Національна квестія» у книзі [Волковський 2017: $63-78]$. 
3) Базова елементарна «національна ідея», тобто ідея, що лежить в основі будь-якої нації: спільнота людей, що прагне суверенно урядувати самих себе згідно своїми руками створених законів. Всі інші ідеї - опціональні, але це базове і апріорне. Можуть бути різні візії того, яким чином себе урядувати - тоді може виникати конфлікт аж до громадянської війни.

Повстають питання щодо сакрального космосу. Насамперед, щодо сакрального простору і часу. Інакше кажучи, яку територію ми можемо окреслювати як «нашу» і до яких глибин в межах минулого ми можемо провести траєкторію становлення української державності. Тут нема місця для глибшого занурення у ці проблеми, але саме конструктивістський, не-есенціалістський підхід до розуміння нації дозволяє відповісти на це просто.

Ці концепти завжди є справою загальної волі і вибору певної нації-спільноти, яка встановлює свій ідеальний вимір. У цій справі $\epsilon$ об'єктивний і суб'єктивний виміри. Україна стоїть на поєднанні етнографічного принципу (історичні межі розселення) і дипломатичного принципу (загальновизнані державні кордони). Ці кордони обгрунтовані саме етнографічним принципом, але далеко не відповідають йому (великі області, більш ніж 20 \% від сучасної території України, здебільшого населені українцями, були асимільовані у ХX ст..). Крим згідно етнографічного та історично-легітимістичного (історична традиційна державність на певній території) принципу має бути кримськотатарським, згідно дипломатичного принципу він безумовно має належати Україні. Російська присутність у Криму - лише наслідок політики імперіалізму і кривавого геноциду.

Щодо «сакрального часу», ми маємо велику інформаційну війну довкола інтерпретації історії України, у якій беруть участь не лише Росія та Україна, але ще і Польща та Угорщина. Цю війну можна умовно розділити на два «фронти». Перший - це «війна за київську спадщину», де іде боротьба довкола інтерпретації історії до XIX ст.., особливо історії слова і поняття «Русь». При цьому обидві сторони використовують різні підходи: російська доктрина «русского мира» спирається на етатистськолегітимістичний підхід («історія великих чинів великих діячів великих держав»), український наратив спирається на етнографічний і культуроцентричний підхід (фокусуючись на реальних спільнотах і реальному побуті тогочасного суспільства), проте також вимальовує історію України у сучасному розумінні цього слова, спрошуючи багаторівневу та відмінну від сучасної систему ідентичності.

Другий - це дебати вже про період «свідомого» модерного націєтворення, що концентруються на центральній події II світової війни. 
Російська пропаганда підносить космогонічний міф «Великої Війни космічного Добра (Дідів) проти космічного Зла», де Росія-СРСР відіграла роль Мардука у битві з Тіамат, перемогла космічне зло і «разом із союзниками» встановила справжній порядок у космосі. Відповідно, минуле жорстко оцінюється як чорно-біле: якщо хтось якось був у співпраці із «світовим Злом», він миттєво таврується і повністю дискредитується. Образом цієї співпраці є «колаборація з фашизмом», а пейоратив «фашизм» активно використовується для ліквідації публічного діалогу і нав'язування вигідної для пропагандистів позиції, при цьому «колаборація» оцінюється вибірково ${ }^{1}$. Проводиться прив'язка понять «націоналізм» і «бандерівці» (з усіма «ОУН», «УПА» і т.п.) і наступна їхня дискредитація. Така маніпуляція спирається на усталені патерни радянської пропаганди та на світовий консенсус, який спирається на глобальну історичну міфологію, що також грунтує світовий порядок на міфології «Великої війни» і Голокосту, де будь-який зв'язок із космічним Злом автоматично дискредитується. Вульгарне спрощення історії породжує інше вульгарне спрощення, коли діячі Визвольного руху і Визвольних змагань безоглядно героїзуються, а критика на адресу канонічних постатей сприймається як напад на цілу політичну спільноту ${ }^{2}$. Тут $є$ суб'єктивний та об’єктивний виміри. 3 одного боку, справа конструювання власного історичного сакрального часу - $є$ суверенна справа певної нації-спільноти, і історичні наративи сусідніх націй дуже рідко взаємно сумісні (хоча б узяти героїзацію Наполеона). 3 іншого боку, є певні етичні принципи, які вимагають дати моральну оцінку різних історичним подіям і діячам, відокремлюючи, «за що ми шануємо X» і «що ми вважаємо неправильним». Ця моральна оцінка не для оцінки гідності минулого, а для формування етики сучасної політики, що має бути пильною щодо «Ніколи знову!» і щодо маніпуляцій цією оцінкою заради досягнення власних інтересів (напр.., коли Росія

\footnotetext{
${ }^{1}$ Саме тому, культ «героїв Великої Вітчизняної» у будь-якому його вигляді (навіть під соусом - «це наші діди, що перемогли фашизм») - $є$ дуже небезпечним і шкідливим. Це відтворює і поширює ідеологічну міфологію, центральні постулати радянської і сучасної російської громадянської релігії. Міфічний образ Дідів - типовий для будь-якої архаїчної міфології. Велика битва Дідів, founding fathers, легітимує існування «нашої» політичної спільноти і наявний світовий порядок. В ментальній мапі цієї міфології Україні немає місця - вона приречена на шизофренічний розрив між двома головними своїми ґвалтівниками, а люди (реальні «діди»), що стали жертвами політики двох кривавих режимів, використовуються для легітимації одного з них.

${ }^{2}$ Слід сказати, що це почасти правда - дуже часто критика і дискредитація українських Визвольних змагань свідомо використовується для делегітимації України і Української Держави загалом, а сучасний активний рух за Україну і українську державність наступним кроком дискредитується через відсилки до вже дискредитованих історичних персонажів (наприклад, «це все бандерівство»).
} 
всіляко експлуатує міф II світової для легітимації сучасного неоімперіалізму і насильства).

Останнє питання про сакральний простір - так яка ж ідея України, який трансцендентний сакрально-моральний горизонт, який легітимує смисл і призначення України? Про це багато говориться, але важко сприймати це без іронії.

По-перше, у постмодерну добу будь-який метанаратив в дусі «вічної ідеї Бога», «що Бог помислив про Росії» В. Соловйова, викликає іронію. У постмодерному суспільстві конструювати таку ідею, що може мотивувати маси - абсурд.

По-друге, такі ідеї вже були синтезовані українськими мислителями у ту добу романтичного націоналізму XIX ст.., коли такі проекти були повсюдними. I з них можна виділити два:

\section{1) «Книга буття українського народу» Кирило-Мефодіївського братства.}

Цей текст унікальний з багатьох ракурсів.

Це - перша політична програма, де Україна фігурує як центральна політична цінність [Бутич et al. 1990]. Вона постала одночасно із маніфестом Головної Руської Ради у Галичині і є прекрасним свідченням природності, справжності українського націєтворчого руху. Дещо спрощено, це початки українського націоналізму - за 100 років до Бандери. Саме братство вплинуло через своїх дуже впливових членів (М.Костомарова, П. Куліша, Т. Шевченка та ін.) на українську свідомість радикальним чином. Цей текст прямо відсилає до польського месіанізму і польського націєтворчого проекту, показує нашу вкоріненість у європейські тренди і розвінчує сучасні міфи протиставлення польської та української нації.

Місія України - глобальне утвердження нового ідеалу суспільно-політичного і морального життя, що спирається на ідеал апостольської християнської спільноти, на цінності свободи, рівності і братерства, на євангельські принципи людяності у ставленні до окремої людини і цілого людства. Україна через свою історію має стати точкою, де почнеться духовне і політичне відродження людства, подолання рабства, насильства і нерівності.

2) Пов'язаність національного із загальнолюдським у громадівському проекті М.П. Драгоманова: «космополітизм (humanité) в ідеях і цілях, національність в грунті і формах культурної праці» [Грінченко, Драгоманов 1990: 190]. 
Національність існує завжди у світлі людськості ${ }^{1}$ i співвідноситься із людськістю як «сутність» та «іпостась» (у теологічних термінах). Людськість не існує поза національним (будь-яка людина має певну мову і походження), проте національне існує лише на основі загальнолюдського (люди всіх національностей насамперед є люди, з їхніми базовими потребами). Заперечення національного обов'язково веде до фактичної асиміляції окремих народів іншими, зростання великих імперій, знищення різноманітності людських народів і культур, що $є$ збіднення людської культури. Будь-який асиміляціонізм та імперіалізм суперечить гуманізмові. Будь-якій культурній людині огидно, коли вимирає біологічний вид чи окремий народ. Різноманіття видів природи $є$ цінністю, і тим не менше, розмаїття різних народів та мов. Космополітизм, що ігнорує цю проблему, прикриваючись соціалістичними чи ліберальними гаслами, насправді $\epsilon$ асиміляціонізмом і шовінізмом окремих імперських націй. Навпаки, національне можливо лише у світлі спільного для всіх людей зростання у свободі і розумі, поступі науки і свободи. Егоїстичний націоналістичний імперіалізм та шовінізм знищує raison d'être нації як такої, взагалі, оскільки її трансцендентальна мета може бути лише благо людини і людськості.

Драгоманівська ідея пов'язана із ідеями братчиків, хоч і позбавлена релігійного, есхатологічного горизонту християнського змісту. Проте це цілком може працювати як секулярна громадянська релігія в дусі американської чи французької громадянської релігії.

3) Наша національна ідея (і громадянська релігія) прекрасно і лаконічно сформульована у пісні «Ще не вмерла Україна», з якої постав наш гімн. Подивугідний талант Павла Чубинського, на рівні духовного натхнення вхопив ледве не сутність українського романтичного сакруму.

Не дивно, що цей гімн постійно намагаються дискредитувати і замінити. Для цього зумисне чіпляються до першого його рядка. Але некомпетентність таких «критиків» одразу видно: починаючи з того, що вони виводять його з польського гімну (не знаючи, що витоком нашого гімну $\epsilon$ сербська пісня про прапор), завершуючи тим, що полякам зовсім не зашкодило така ж сама тональність першого рядка. Бо справа у тому, що кажуть наступні куплети - і невипадково, що проросійська влада прибрала другий і третій куплети, не кажучи вже про всі інші.

Його можна довго розбирати, але я виділю лише кілька ідей. Перше: маркування сакрального простору і часу - «від Сяну до Дону», «Дніпро», «Чорне море» і перерахунок постатей козацької доби (тобто стверджен-

\footnotetext{
${ }^{1}$ Людськість у словнику XIX ст. означає одразу три поняття - «людська природа, чим $€$ людина сама по собі», «людство як цілісність», «людяність як моральний принцип (гуманізм)». Це є дослівний аналог французького humanité.
} 
ня непорушної тяглості нашої боротьби крізь останні 300 років). Чітке маркування ворожості Московії: «Ой Богдане, Богдане, ... нащо продав Україну москалям поганим» (і це 1862 рік, Київ!). Базова цінність: «А завзяття, щира праця ще свого докаже / Ще ся волі в Україні піснь гучна розляже, / За Карпати відоб'ється, згомонить степами, /України слава стане поміж народами». Завзяття і щира праця - важливий мотив. Слово «завзяття» саме по собі погано перекладається іншими словами, як і слово «затятість». Це наш Sturm und Drang, непохитна воля до боротьби, що б там не було, хоч би і небо проти нас - але завзята щира праця лупає будь-яку скалу (словами I. Франка). Праця - не насильство і не лежання. «Бо плач не дав свободи ще нікому, А хто борець, той здобуває світ» відгукується на це гімн ОУН 1932 р., вкорінений у «Борітеся - поборете» Т. Шевченка і «Дух, що тіло рве до бою» І. Франка. Україна постає із завзятої праці і несхитної волі до боротьби.

I окрема тональність - це панславістський мотив: «Поєднаймось разом всі, / Братчики-слав'яне: / Нехай гинуть вороги, / Най воля настане!», який походить ще з «Книги буття українського народу». Україна повстає в контексті слов'янського визвольного руху, і фундаментальна мета - «воля». Це був конкурентний виклик російському імперіалістичному панславізму і заявка на моральне лідерство регіональне, а відтак і світове. Можна довго сперечатися про це, але те, що Україна повинна працювати насамперед у цьому контексті - важко заперечити.

\section{Висновки}

Епохальний ювілей змушує замислитись про те, що було, є і буде пережите і зроблене. Що ж можна сказати через 30 років після здобуття Незалежності? Які практичні висновки, зокрема і особливо, для нашої школи, системи освіти, для виховання свідомості відповідального громадянина? Ці висновки умовно можна поділити на дві групи: філософсько-історичні висновки щодо підходу до розуміння і викладання історії України та політично-філософські висновки щодо підходу до розуміння сучасних актуальних подій, сучасних дискусій в межах українського суспільства, зокрема, довкола питань «що таке Україна?», «чому вона повинна існувати?», «що вона значить для нас?», «як пояснити війну, що досі триває?», «яке місце України у світі тощо?».

Базовою настановою повинен бути україноцентризм. Це не означає, що ми повинні поділяти наївний есенціалістський і авторитарний підхід у цій справі - примордіалістську ідею тисячолітнього походження чи однозначної об’єктивної «ментальної сутності» чи «природи». Це може лише зашкодити. Проте в межах модерного конструктивістського підходу є цілком тверді основи, на які можна спертися. Ми можемо 
відштовхуватися від Драгоманівського розуміння єдності національного і людського - не існує людини окремо від нації і для культурної людини будь-який асиміляціонізм і колоніалізм $є$ огидний. Україна $\epsilon$ наше політичне тіло і наша уявлена політична спільнота, яка є вищою політичною цінністю (при цьому, «вища політична цінність»не означає «вища цінність» взагалі, вона обумовлює лише нормативні критерії щодо нашої політичної думки і дії) ${ }^{1}$. Вона має об’єктивні витоки свого існування - це і емпіричний факт існування етнокультурної спільноти українського народу, історія якого цілком може коректно проведена крізь останнє тисячоліття, і традиції політичного і культурного життя, що так чи інакше лягли в основу модерної української політичної нації-спільноти. Звісно, суб’єктивний вимір існує - це насамперед та спонтанність історії і політики, яка спричинилася до того, що Україна сформувалася саме так і в таких межах. Проте суб'єктивне і об’єктивне не повинні знецінювати одне одного.

Україна відбулася - як держава і як політична нація. Історія української політичної нації (як модерної форми організації суспільства) налічує щонайменше 200 років. На початках вони спиралася на активність еліт козацької Гетьманщини, клерикальних еліт Галичини і різнорідних складників інтелектуальної еліти. Цей націєтворчий проект - «центральноєвропейського» типу, що починався з культурницького руху українофільства і поступово формулював свою політичну аґенду. Вона має онтологічну основу в межах меж етнографічного розселення (що взяті станом на «точку відліку»- початок XIX ст.). Відлік постання української нації-спільноти можна вести від «Книги буття українського народу» 1846 р. і Маніфесту Головної Руської Ради від 10 травня 1848 р., коли було засвідчено політичний проект української (руської) нації в межах етнографічного розселення українців. Українська нація-спільнота перетворюється на масовий рух у період 1890-1917 pp., і у 1917 - 1918 рр. здобуває своє політичне тіло (УНР, ЗУНР тощо), яке з того часу існує безперервно (хоча б і фіктивно, як УРСР). 1991 р. українська нація остаточно здобуває своє тіло як нація-держава.

Україна змогла вистояти перші найскладніші з точки зору стабільності системи роки і простояти 30 років. Це - на 10 років більше, ніж міжвоєнний період, коли існували Польща чи країни Балтії. При цьому, Україна впродовж 23 років свого існування була єдиною з колишніх республік СРСР (без краӥн Балтї̈), яка зберегла мир, уникнула громадянських воєн, кровопролить і втрат території, при цьому не ставши диктатурою. Стійкість української системи виявилась до-

${ }^{1}$ Перефразовуючи С. Бандеру: «свобода України - свобода людини». 
статньою для того, що для її руйнування Росії довелося починати з прямого збройного вторгнення (окупація Криму і Іловайськ) і постійного відвертого збройного втручання.

Проте війна України за незалежність не завершена. Її відлік можна коректно починати з Перших визвольних змагань 1917 - 1921 рр., зображуючи історію XX ст.. як чергування різних етапів цієї боротьби. Перемога 1991 р. справила фатально хибний заспокійливий вплив, що спричинив нерозуміння більшістю українського суспільства цього виміру політичного буття. Це стало однією з причин, що уможливила російську агресію 2014 р. Історію з 1991 р. можна зображувати як триваючу незавершену Українську революцію, що має національно-визвольний та ліберально-демократичний виміри, і мала три emanu («три Майдани» - 1991, 2004, 2013-2014 рр.). Сучасна стадія «гарячої» війни - лише черговий етап столітньої історії. Ця історія не буде завершена до розв'язки сюжету цієї драми - протистояння імперії $\boldsymbol{i}$ повсталої колонії, що бореться за незалежність. Доки імперія не відмовиться від свого імперіалізму, доки остання імперія Європи не перетвориться на демократичну націю (можливо, це відбудеться лише внаслідок розпаду Російської колоніальної імперії так, як це сталося навіть з Британською імперією) - доти не завершиться наша війна, i доти триватимуть відлуння Великої війни, що почалася 1914 р.

Саме тому провалились всі пошуки «об’єднавчої ідеї», що мала би об’єднати міфічний «схід і захід». Неможливо об'єднати вовка і зайця, лоялістів авторитарної імперії та громадян повсталої незалежної нації. У них два протилежних сакральні космоси, це - різні галактики. Для нас вища політична цінність $є$ Україна, для них горизонтом їхнього політичного світогляду $є$ «Отечество от Москвы и до окраин». Завдання-питання про «об’єднання» поставлене спочатку хибно - хіба що якщо на меті об'єднати один народ від Чопа до Уелена. Натомість, об'єднання українців (у сенсі політичної нації), здається, є давно фактом. Тоді питання має формулюватися інакше: як охопити лоялістичне проімперське та байдуже невизначене (орієнтоване на цінності виживання) населення, як успішно протистояти імперському наративу, який іде у контрнаступ, де, як і за допомогою чого імперський наратив тримається в Україні? Таке питання - не суто українське, воно тотожне таким же питанням у Білорусі, країнах Балтії тощо.

Школі і системі освіти належить центральне значення у цій справі. Саме освіта $є$ головним джерелом поширення і підтримки (останнім часом, також 3MI, але школа зберігає первинне значення). Саме тому слід дуже уважно підходити до того, які ідеї, поняття та уявлення ми транслюємо. Саме тому дуже небезпечним є примітивне повторення радянсько-російського міфу про «дідів, що воювали» і взагалі наративу 
II світової війни. Україноцентричний підхід несумісний із радянсько-російським наративом, хоч він і інкорпорований в світову ідеологічну матрицю, глобальний сакральний космос. ${ }^{1}$. Україноцентрична оптика, яка свідчить про столітню війну за незалежність України, може розглядати II світову лише у двох перспективах:

1) протистояння двох ворожих щодо України, кривавих тоталітарних режимів, що однаково застосовували засоби геноциду, концтабори, масові репресії, однаково заперечували реальність і право на існування українців як окремої політичної нації;

2) величезну катастрофу Людяності, коли планета поринула у морок взаємного знищення, і землі Центрально-Східної Європи стали основними теренами цієї масакри. Всі трагедії цього періоду треба розглядати у контексті великої катастрофи Людяності і розлюднення. При цьому слід пам'ятати, що події ІІ світової не ізольовані від попереднього і наступного контекстів - вони постали із катастрофи І світової, кривавих репресій СРСР, Голодомору, і вони продовжуються досі. Бабин Яр є живим свідченням цього - як СРСР всіляко фальсифікував його пам'ять і досі намагається його хибно проінтерпретувати, як за Бабиним Яром забувається Биківня.

Але II світова війна не є єдиним пунктом - важливо пам'ятати тяглість, сором і велич української боротьби, і бути пильним щодо типових міфологем російсько-радянської історії. Доктрина «Русского мира» спирається на забуття реальної історії, коли міф про «возз'єднання» і «братні народи / один народ» витісняє пам'ять про реальні історичні відмінності та інакшості. Мова не лише про зраду Березневих статей, вікові репресії проти української мови та ідентичності, гібридні «республіки» 1917 р., трагедію Батурина чи Запорожжя. Мова про реальну історію, яка завжди містить більше розривів і нюансів, а всілякі великі традиції - це уявні ретроспективні генеалогії. Етнографічні відмінності X - XIII ст.., що не збігається з сучасними кордонами, руський (український і білоруський) внесок у Річ Посполиту і Велике князівство Литовське, і т.д. - засвідчать цей момент.

Одна з головних проблем громадянської освіти - це ставлення до України у контексті розуміння сучасного стану. І з огляду на вищевикладене, хочеться виокремити два основні пункти:

1) Національна реальність спирається на афективно-ірраціональне начало, а не на раціональні аргументи. Раціональне лише постає як аргументація вже зробленого вибору на основі ірраціональної відда-

${ }^{1}$ Див. мою статтю про це «Танці на кістках чи бенкет під час чуми: Україна - сліпа пляма на мапі світової пам'яті» за посиланням: https://wwolkowski.blogspot. com/2020/05/blog-post.html 
ності, любові. Як у антиноміях Канта, ми можемо 100\% довести тезу А (напр., «Україна має існувати») і одразу ж її спростувати та довести тезу не-А. Але фінальне рішення приймає любов, яка стверджує буття і проголошує, від «Любіть Україну» В. Сосюри до слів Гузара: «Душу й тіло ми положим за нашу свободу».

2) Успіх певної нації і перемога у національному протистоянні - справа, на яку впливає багато чинників, але завжди важливі воля і розум, «завзяття і щира праця». Спроба віктимблеймінгу ${ }^{1}$ - глибоко хибна і аморальна. У цій боротьбі - як і у будь-якій боротьбі, з часів Сунь Цзи і Фукідіда - переможе той, хто має вперту і несхитну волю до боротьби, віру у власний принцип («На цьому я стою і інакше не можу!»).

\section{Посилання:}

Андерсон, Б. (2001). Уявлені спільноти: міркування щодо походження й поширення націоналізму / пер. з англ. В. Морозова. Київ: Критика.

Бутич, М. І., Глизь, І. І., Франко, О. О. (упор.). (1990). Кирило-Мефодіївське товариство: у 3-х т. Акад. наук УРСР. Археогр. комісія та ін. Київ: Наук. думка.

Волковський, В.П. (2017). Ідея суспільності: політична філософія в Україні XIX століття. К.:, ВД «Академперіодика».

Гараджа, В. И. (2007). Социология религии. Учебное пособие. 3-е издание. М.: ИНФРА-М.

Гобсбаум, Е. (2010). Нації і націоналізм, починаючи з 1780 року: програма, міфи, реальність / пер. і прим. Т. Корпала. Київ: УЦДК.

Грінченко, Б..Д., Драгоманов, М. П. (1994). Діалоги про українську національну справу/ Київ: Нац. акад. наук України. Ін-т укр. археографії

Робінсон, Дж., \& Аджемоглу, Д. (2016). Чому нації занепадають? Походження влади, багатства і бідності / пер. з англ. О. Дем'янчука. Київ: Наш Формат.

Руссо, Ж.-Ж. (2001). Про суспільну угоду, або принципи політичного права / пер. з фр. та ком. О. Хома. К: Port-Royal.

Казанова, Х. (2017). По той бік секуляризації. Релігійна та секулярна динаміка нашої глобальної доби / пер. з англ. О. Панича. Київ: ДУХ І ЛІТЕРА.

Манан, П. (2009). Доступний виклад політичної філософії / Пер. з фр., післямова та прим. С. Йосипенка. -К.: Укр. Центр духов. культури.

Миллер, А. (2013). Украинский вопрос в Российской империи. К.: Laurus.

1992: останній президент УНР передає Кравчуку клейноди Історична правда. (2012). https://www.istpravda.com.ua/videos/2012/01/22/69657/

Bellah, Robert N. (1967). "Civil Religion in America”. Dædalus, 96(1), 1-21.

\section{References:}

Anderson, B. (2001). Imagined Communities: Reflections on the Origin and Spread of Nationalism / transl. from English by V.Morozov. Kyiv: Critique. [In Ukrainian].

Bellah, R. N. (1967). Civil Religion in America. Dædalus, 96(1), 1-21.

\footnotetext{
${ }^{1}$ Коли на жертву (жертв) злочину, нещасного випадку або будь-якого виду насильства покладається повна або часткова відповідальність за вчинене щодо них порушення або нещастя, що з ними відбулося.
} 
Butych, M. Hlys, I., Franko O. (arrang.). (1990). The Brothehood of St. Cyril and Methodius. In 3 volumes. Kyiv: Naukova Dumka. [In Ukrainian].

Casanova, J. (2017). On the Other Side of Secularisation, Religious and Secular Dynamics of Our Global Age / Transl. by O. Panych. Kyiv: DUKH I LITERA. [In Ukrainian].

Haradzha, V. I. (2007). Sociology of Religion. Manual..., $3^{\text {rd }}$ edition. M.: INFRA-M. [In Russian].

Hobsbawm, E. (2010). Nations and Nationalism Since 1780: Programme, Myth, Reality [transl. from Eng. By T. Korpal]. Kyiv: UCDK. [In Ukrainian].

Hrinchenko, B., \& Drahomanov, M. (1994). Dialogues on Ukrainian National Affairs. Kyiv: NAS of Ukraine etc. [In Ukrainian].

Manent, P. (2009). Cours familier de philosophie politique / transl. and commented from French by S. Yosypenko]. Kyiv: UCDK. [In Ukrainian].

Miller, A. (2013). Ukrainian Question in Russian Empire. K: Laurus. [In Russian].

Robinson, J., \& Acemoglu, D. (2016). Why Nations Fail. The Origins of Power, Prosperity, and Poverty / transl. from English by 0. Demyanchuk. Kyiv: Nash Format. [In Ukrainian].

Volkovskyi, V. P. (2017). Idea of Sociality: Political Philosophy in 19th century Ukraine. Kyiv: Publishing House «Academperiodika». [In Ukrainian].

1992:ThelastpresidentoftheUkrainianPeople'sRepublicpasses Kravchukjewels Historical Truth. (2012). https://www.istpravda.com.ua/videos/2012/01/22/69657/. [In Ukrainian].

\section{Volodymyr Volkovskyi. Independence in opposition to the "Russian world": a philosophical and pedagogical dimension}

In the article, the author analyzes some political and philosophical dimensions and perspectives that become relevant on the occasion of the 30th anniversary of Ukraine's Independence. The author, positioning himself within the political philosophy and philosophy of history, points out several fundamental points relevant to the identity and positioning of Ukrainian society on "eternal issues of Ukrainian society", such as discussions on the national idea, national identity, its historical and spatial perspective. The author's presentation is divided into four points: the century-old perspective of the Ukrainian struggle for independence, definition of the current Ukrainian situation in the context of nation-building and confrontation with Russia, the theoretical dimension of "national idea" and "civil religion", practical conclusions about the Ukrainian kind of these concepts. The author relies on the methodology of modern Nationalism Studies, Postcolonial Studies, the experience of Ukrainian studies, especially in the era of Ukrainian modernity (XIX-XX centuries). He postulates that the thirtieth anniversary of Ukrainian independence is inextricably linked with the century of liberation struggles of the Ukrainian nation, that the situation in Ukraine, in particular in the context of defining national identity and confrontation with Russia, can be correctly described as a confrontation between independentists of a modern emerging nation and the colonial empire, which fights for regaining its power over the former colony-province, relies on its numerous loyalists and uses various methods of aggression (both "cold" cultural war and "hot" military confrontation) to subdue the region. The author offers his view on the 
concept of "Ukrainian national idea", based on the basic literary sources of the history of Ukrainian nation-building. Based on the research, the author offers certain practical conclusions important for teaching history, law, civic education and for the education of a responsible citizen in Ukraine.

Keywords: independence of Ukraine, nation-building, Nationalism Studies, Postcolonial Studies, political philosophy, national idea, national identity, civil religion, civic education.

Володимир Волковський - кандидат філософських наук, науковий співробітник відділу історії філософії України Інституту філософії імені Г.С. Сковороди НАН України, магістр філософії Національного педагогічного університету імені М.П. Драгоманова, викладач предметів соціально-гуманітарного напряму.

E-mail: dinginnalu@gmail.com

https://orcid.org/0000-0002-4674-3956

Volodymyr Volkovskyi - Ph.D., Researcher of the Department of History of Philosophy of Ukraine at Skovoroda Institute of Philosophy, NAS of Ukraine, Master of Philosophy of Drahomanov National Pedagogical University, teacher of social sciences and humanities.

E-mail: dinginnalu@gmail.com

https://orcid.org/0000-0002-4674-3956 